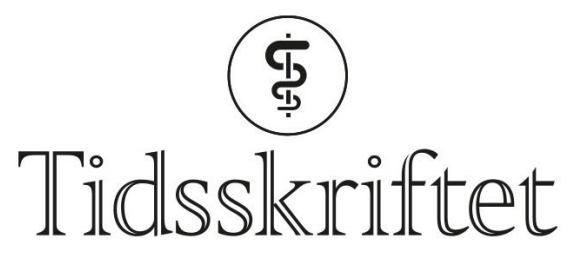

DEN NORSKE LEGEFORENING

\title{
Hudkreft blant organtransplanterte
}

FRA ANDRE TIDSSKRIFTER

ERLEND HEM

Tidsskriftet

Risikoen for å utvikle kutant plateepitelkarsinom etter organtransplantasjon er ikke like høy som før, viser en ny norsk studie. Nedgangen skyldes antagelig mindre aggressiv immundempende behandling.

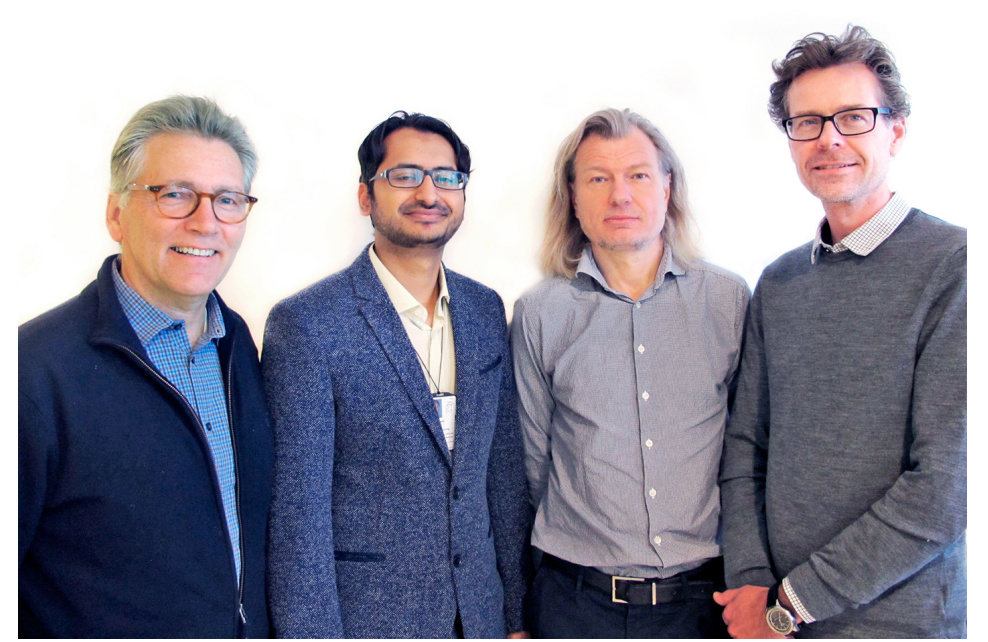

Fra venstre Petter Gjersvik, Mohammad Rizvi, Bjarte Aagnes og Bjørn Møller, som sammen med transplantasjonsmedisinere ved Oslo universitetssykehus sto bak studien. Foto: Gunther Zerener, Kreftregisteret

Organtransplanterte har svært høy risiko for å utvikle hudkreft, særlig plateepitelkarsinom (1). Årsaken er knyttet til de immundempende legemidlene som pasientene må bruke for å hindre avstøtning av det transplanterte organet.

I en kohortstudie med alle pasienter som ble nyre-, hjerte-, lunge- eller levertransplantert i Norge i perioden 1968-2012, dvs. over 8 ooo pasienter, har norske forskere nå påvist en sikker nedgang i forekomsten av kutant plateepitelkarsinom etter transplantasjon siden begynnelsen av 1990-årene (1). Akkumulert risiko de første 15 årene etter transplantasjon $\emptyset$ kte kraftig hos dem som ble transplantert i perioden 1983-87, men avtok så gradvis blant dem som ble transplantert i 1993-2002 og 2003-12. Beregninger av standardisert insidensratio (SIR), der forekomsten av kreft sammenlignes med en alders- og kjønnsparet befolkning i samme tidsperiode, bekreftet en markert nedgang i risikoen for plateepitelkarsinom. Risikoen var høyest for dem som ble transplantert i 1983-87 og 1988-92, dvs. rundt 100 ganger høyere enn i den generelle befolkningen. Deretter sank risikoen til under det halve sammenlignet med dem som ble transplantert i 1983-87, også 
etter å ha justert for ulik oppfølgingstid.

- Dette er den første større, registerbaserte studien som viser en klar nedgang i risikoen for plateepitelkarsinom i hud etter organtransplantasjon, forteller Mohammad Rizvi, artikkelens førsteforfatter. Studien er nylig publisert i JAMA Dermatology, som er et av de høyest rangerte tidsskriftene innen dermatologi. Øvrige forfattere er Bjarte Aagnes og Bjørn Møller ved Kreftregisteret og transplantasjonsmedisinere ved Oslo universitetssykehus med Petter Gjersvik som prosjektleder og sisteforfatter.

- Nedgangen i risikoen for plateepitelkarsinom kan forklares med en mindre aggressiv og mer individualisert immundempende behandling etter organtransplantasjon, sier Rizvi. Han understreker at risikoen for å utvikle hudkreft etter organtransplantasjon fortsatt er høy. Denne studien viser at risikoen nå er 30-45 ganger høyere enn i den generelle befolkningen. Pasientene må derfor være særlig nøye med å begrense eksponeringen for sol og beskytte huden mot overdreven soling. Huden må sjekkes regelmessig av pasienten, av pårørende og ved legekontroller. Noen pasienter utvikler multiple hudkreftlesjoner, og disse må følges opp særskilt av hudleger, sier Rizvi.

Oslo universitetssykehus er et av verdens største transplantasjonssentre med over 400 organtransplantasjoner hvert år. Med transplantasjonsvirksomheten samlet ved ett sykehus og et velfungerende nasjonalt kreftregister egner Norge seg godt til å studere eventuelle endringer i kreftforekomst etter organtransplantasjon.

LITTERATUR:

1. Rizvi SMH, Aagnes B, Holdaas H et al. Long-term change in the risk of skin cancer after organ transplantation. A population-based, nation-wide cohort study. JAMA Dermatol 2017; e-publisert 18.10.2017.

Publisert: 28. november 2017. Tidsskr Nor Legeforen. DOI: 10.4045/tidsskr.17.088o

(C) Tidsskrift for Den norske legeforening 2020. Lastet ned fra tidsskriftet.no 